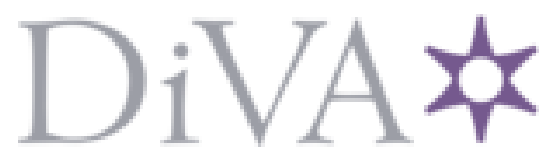

http://www.diva-portal.org

\title{
Postprint
}

This is the accepted version of a chapter published in Towards European science: Dynamics and change in science policy and organization.

Citation for the original published chapter:

Engwall, L. (2015)

Academies and their roles in policy decisions.

In: Linda Wedlin \& Maria Nedeva (ed.), Towards European science: Dynamics and change in science policy and organization (pp. 147-174). Cheltenham: Edward Elgar Publishing

N.B. When citing this work, cite the original published chapter.

Permanent link to this version:

http://urn.kb.se/resolve?urn=urn:nbn:se:uu:diva-280051 


\section{Academies and their roles in policy decisions}

\section{Lars Engwall}

\section{INTRODUCTION ${ }^{1}$}

Standing on the shoulders of Plato and his school in Academia outside Athens, modern academies emerged from Renaissance Italy in the fifteenth century and onwards, and can today be found all over the world. Although not always very visible, they play an important role in policy decisions. They do so in two respects: policy for science and science for policy (Engelbrecht and Mann 2011: 19), that is, providing input for decisions (1) on the allocation of resources, academic governance and other conditions for research, and (2) on other significant political issues. ${ }^{2}$ In the first case it is a question of to what extent and how tax-payers' money should be allocated to higher education and research, while the second type of input implies the offering of expertise to politicians regarding issues such as energy, the environment, and health.

Of these two tasks the former, science policy, can be regarded as promoting the latter: i.e. the more attention society pays to research and higher education, the more opportunities to provide input for other strategic decisions. It can even be argued that science policy to a certain extent, particularly before Putin came to power, has taken over the role of defence policy during the past few decades (Engwall 2005): military expenses have been on the decline in many countries, while spending on research and higher education has gone in the other direction. In other words, economic power in relation to other countries (Porter 1990) has become more in focus than the military power. Competitiveness based on knowledge supremacy is the gospel. As stated by the 1965 Nobel Laureate in Medicine and Physiology, François Jacob: ${ }^{3}$

The power of a nation was long measured by that of her army. Today, it is rather evaluated by her scientific potential.(my translation)

Like defence policy, science policy is facing increasing challenges (Lane et al. 2011). In this struggle, all voices are not listened to with 
Prepublication version of chapter published in Linda Wedlin and Maria Nedeva (eds), Towards European Science: Dynamics and Change in Science Policy and Organization, 2015,

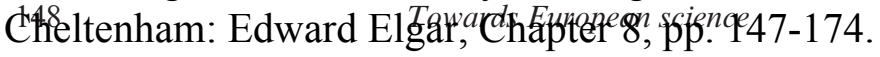

equal effectiveness. Therefore reputation is an important feature of the system. And, this reputation is built on the gradual admission into successively more prestigious scientific elites. In this process, universities through their career systems are crucial, but so are academies. Although many of them were once founded as a complement to, or in competition with, universities, today they constitute important devices for the selection of scientific elites. In this way these organizations have also acquired a signficant impact on policy decisions. The reason is that academies are supposed to host the outstanding members of scientific disciplines.

Against the above backdrop, the present chapter aims at demonstrating the role of academies in policy decisions. For this purpose the following section will briefly summarize the development of academies over time. This exposition will be followed by an analysis of the characteristics of academies. It will point to the two important roles expressed in mission statements of academies: (1) international collaboration and (2) interaction with society. These roles are played both by individual members and the national academies themselves. However, like many other organizational fields, that of academies has seen the emergence of organizations that organize individual organizations, labelled meta-organizations by Ahrne and Brunsson (2008). The development of these international organizations will be summarized in a subsequent section, followed by one dealing with the relationship between European academies and society. A final section will present conclusions.

\section{The Emergence of a Population of Academies}

As pointed out by way of introduction, academies constitute a successful organizational form diffusing from Renaissance Italy to other European countries and the rest of the world (Figure 8.1 and Table 8.1). Academies were thus founded in Italy as early as the fifteenth century, although many of them disappeared. The oldest still existing academy is therefore Accademia dela Crusca, which was founded in 1583. Oriented towards languages, it published a first edition of an Italian dictionary in 1612, and became the role model for many other academies, among them the French l'Académie française from 1635. Later in the seventeenth century this academy was followed by two others in France, both founded by Jean-Baptiste Colbert: l'Académie des inscriptions et belles-lettres in 1663 and l'Académie des sciences in $1666 .{ }^{4}$

Parallel developments occurred in Germany and the United Kingdom. In 1652 the oldest continuously existing academy of sciences - as of 2007 Deutsche Akademie der Wissenschaften Leopoldina - was founded as 


\section{Prepublication version of chapter published in Linda Wedlin and Maria Nedeva (eds), Towards European Science: Dynamics and Change in Science Policy and Organization, 2015,

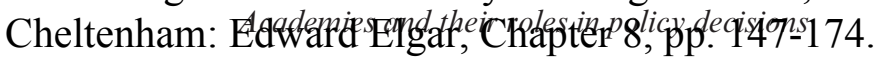

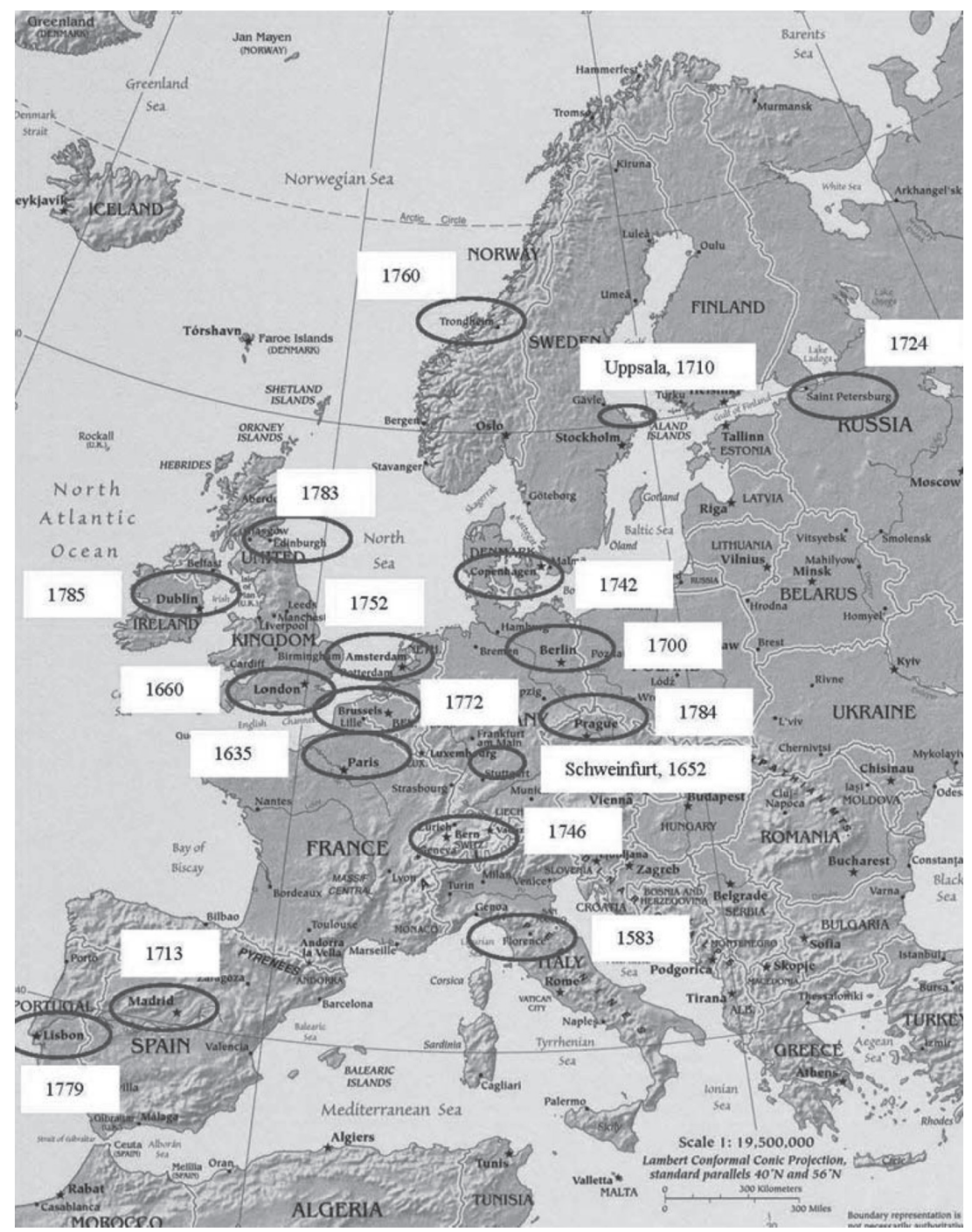

Sources: http://www.accademiadellacrusca.it, http://www.institut-de-france.fr/fr/uneinstitution/son-histoire. Hahn (1971), Leopoldina (2010), Bryson (2010), http://www.bbaw. de, Engwall (2012), http://www.rae.es, Hildebrand (1939, p.45), http://www.royalacademy.dk, http://www.amphilsoc.org/, http://www.ngzh.ch/, http://www.khmw.nl, http://www.dknvs.no, http://www.academieroyale.be, http://www.acad-ciencias.pt, http://www.royalsoced.org.uk, http://www.cas.cz/o_avcr/historie/, http://www.ria.ie and Grau (1988).

Figure 8.1 Geographical distribution of the early academy foundations 
Prepublication version of chapter published in Linda Wedlin and Maria Nedeva (eds), Towards European Science: Dynamics and Change in Science Policy and Organization, 2015,

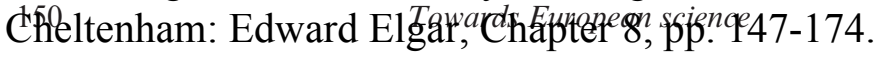

Table 8.1 Academy pioneers in different countries

\begin{tabular}{llll}
\hline Year & Name & Country & Location \\
\hline 1583 & Accademia dela Crusca & Italy & Florence \\
1635 & l'Academie française & France & Paris \\
1652 & Academia Naturae Curiosorum & Present Germany & Schweinfurt \\
1660 & Royal Society & United Kingdom & London \\
1700 & Preußische Akademie der & Prussia & Berlin \\
& Wissenschaften & & \\
1710 & Royal Society of Sciences at Uppsala & Sweden & Uppsala \\
1713 & Madrid Real academia española & Spain & Madrid \\
1724 & Rossi'iskaya akade'miya nau'k & Russia & St. Petersburg \\
1742 & Det Kongelige Danske & Denmark & Copenhagen \\
& Videnskabernes Selskab & & \\
1743 & American Philosophical Society & USA & Philadelphia \\
1746 & Naturforschende Gesellschaft & Switzerland & Bern \\
1752 & De Hollandsche maatschappij der & The Netherlands & Haarlem \\
& wetenschappen & & \\
1760 & Det Kongelige Norske Videnskabers & Norway & Trondheim \\
& Selskab & & \\
1779 & Academia das Ciências de Lisboa & Portugal & Lisbon \\
1783 & Royal Society of Edinburgh & Scotland & Edinburgh \\
1784 & Die Böhmische Gesellschaft der & Bohemia & Prague \\
& Wissenschaften & Ireland & Dublin \\
1785 & Royal Irish Society & & \\
\hline
\end{tabular}

Sources: See Figure 8.1.

Academia Naturae Curiosorum..$^{5}$ As an academy of sciences, it was followed by the Royal Society in Britain in 1660 and the above-mentioned l'Académie des sciences in France in 1666.

In the eighteenth century, as also shown in Figure 8.1 and Table 8.1, the academy as an organizational form spread all over Europe from Trondheim in the north (1760) to Lisbon in the south (1779). It started out with Preußische Akademie der Wissenschaften founded in Berlin by Gottfried Wilhelm von Leibniz in 1700. And, an early follower with direct inspiration from the Berlin academy was the Swedish Royal Society of Sciences from $1710 .{ }^{6}$ Academy foundations in most European countries thus followed. The academy form also spread to the United States in 1743 through the American Philosophical Society in Philadelphia. $^{7}$

Further development in the nineteenth century included the diffusion of academies to Eastern Europe: Budapest (1825), Zagreb (1861), 
Prepublication version of chapter published in Linda Wedlin and Maria Nedeva (eds), Towards European Science: Dynamics and Change in Science Policy and Organization, 2015,

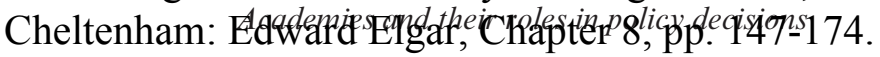

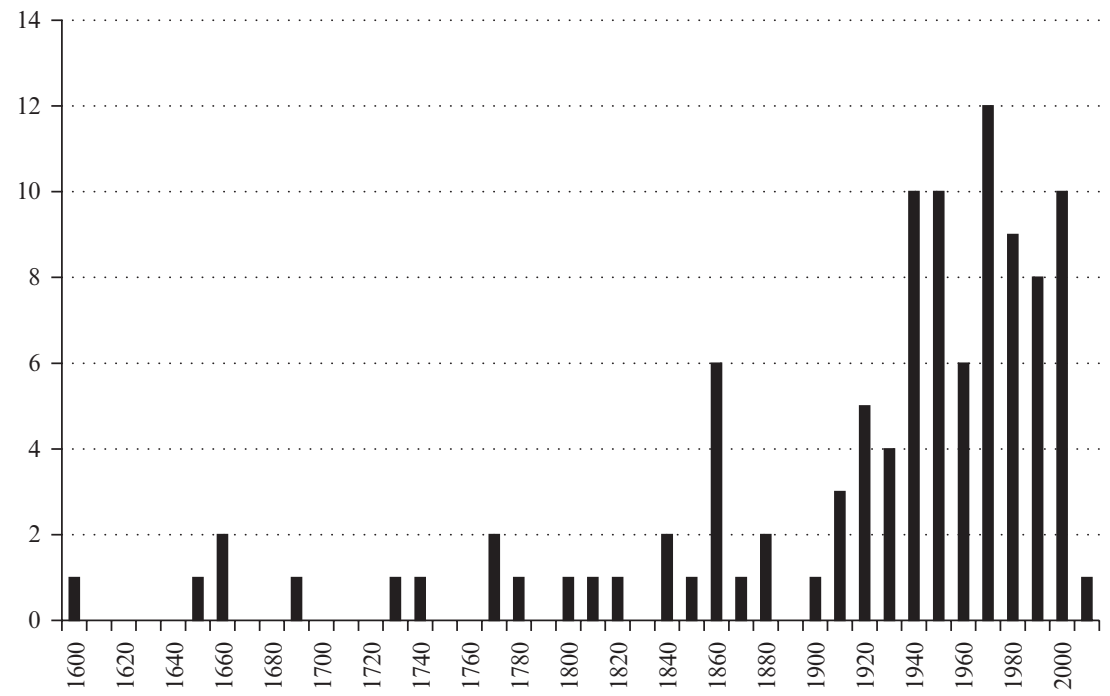

Source: Adaptation of data provided on http://www.interacademies.net. Foundation years for a few members are missing, but that will not influence the general picture.

\section{Figure 8.2 Decades of establishment for Inter Academy Panel Members}

Warszaw (1872), and Belgrad (1886). ${ }^{8}$ In addition, the academy form spread outside Europe within the British Empire (New Zealand, 1867; South Africa, 1877; and Canada, 1882) and to South America (Argentina, 1869; Brasil, 1916; Colombia, 1933). ${ }^{9}$ However, as can be seen in Figure 8.2, which provides further data for most national members of the InterAcademy Panel (see further below), relatively few of the members were founded before the twentieth century. Only one-fourth were thus created before 1900, and they were predominantly European ( 80 per cent). Then, there were establishments in the Americas and Asia, and in the 1950s and onwards also in Africa.

Although Figure 8.2 can be considered to provide a general picture of developments, it is just a part of the world academy population, since it is limited to InterAcademy Panel members. This is important to note, as there is a much larger number of other academies worldwide, some with other orientations and others constituting competing or supplementary national academies. ${ }^{10}$ An example of a new orientation is the Royal Swedish Academy of Engineering Sciences, which was the first of its kind at its foundation in 1919. Eventually there were successors, first in the Nordic countries, later on in the rest of the world, counting nowadays more than twenty sister academies. ${ }^{11}$ 
Prepublication version of chapter published in Linda Wedlin and Maria Nedeva (eds), Towards European Science: Dynamics and Change in Science Policy and Organization, 2015,

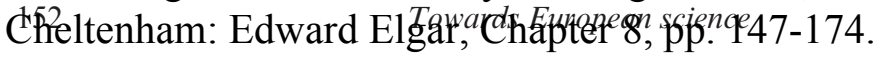

The existence of competing and supplementary academies can be illustrated by developments in Sweden. As can be seen in Table 8.2 the number of Swedish academies with Royal charters is presently 18 with different orientation and recruitment: six have broad orientation, six are oriented towards the humanities, four gather professional groups and two are artistic. Eleven have a national recruitment, while seven basically recruit members from four university communities. Even if not all countries have the Swedish broad spectrum of academies, this is a further demonstration of the successful diffusion of the academy as an organizational form.

It is also appropriate to mention that academy foundations in the twentieth century crossed national borders. A relatively new entrant to the population of academies is thus Academia Europaea, which is a transnational academy with members mostly from European countries but also from some non-European ones. It was founded in 1988 at a meeting of the European Ministers of Science in 1985, at the initiative of a number of departing members of the Board of the European Science Foundation. Twenty-five years later it had more than 2,000 members from a very wide range of disciplines and is managed from an office in London. ${ }^{12}$ As is often the case, other initiatives appeared at the same time. In 1990 thus a group of Austrians founded the European Academy of Sciences and Arts, located in Salzburg, also transnational and interdisciplinary in character. And, in the first years of the present century another European academy was created: the Belgium-based European Academy of Sciences. ${ }^{13}$

This tendency to create transnational academies is not unique to Europe. For the developing countries a project of this kind was thus launched in 1983 through the foundation of the Academy of Sciences for the Developing World (TWAS). Thirty years later it has 588 members from 76 countries and a secretariat in Trieste, Italy. ${ }^{14}$ Likewise the Islamic World Academy of Sciences (IAS) was founded in 1987; today it has about 100 fellows representing 35 nationalities. ${ }^{15}$ As a matter of fact as early as 1960 the World Academy of Art and Science (WAAS) was created "for distinguished scientists and scholars to discuss the vital problems of mankind, independent of political boundaries or limits - whether spiritual or physical; a forum where these problems will be discussed objectively, scientifically, globally and free from vested interested or regional attachments". Presently it has 650 individual members "from diverse cultures, nationalities, and intellectual disciplines". ${ }^{16}$

This brief summary not only demonstrates a diffusion of the academy as an organizational form, it also points to the fact that it includes different types. Some, like Leibniz's academy Preußische Akademie der Wissenschaften, are broad comprising both the natural sciences and the 


\section{Prepublication version of chapter published in Linda Wedlin and Maria Nedeva (eds), Towards European Science: Dynamics and Change in Science Policy and Organization, 2015,

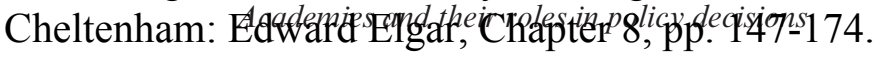

\section{Table 8.2 Orientation and recruitment of Swedish academies with Royal charters}

\begin{tabular}{ll}
\hline \multicolumn{1}{|c}{ Recruitment } & National (11) \\
\hline $\begin{array}{l}\text { Orientation } \\
\text { Natural sciences, } \\
\text { medicine, humanities }\end{array}$ & $\begin{array}{l}\text { The Royal Academy of } \\
\text { Sciences (1739) }\end{array}$
\end{tabular}

and social sciences (6)

Humanities (6)

Professional groups (4)

Artistic (2)
Local (7)

The Royal Society of

Science at Uppsala

(1710), the Royal

Physiographical Society

at Lund (1772), the Royal

Society of Arts and

Sciences in Gothenburg

(1778), the Royal Society

of Arts and Sciences of

Uppsala (1954), the Royal

Skytteanian Society at

Umeå (1956)

The Royal Society of the

Humanities at Uppsala

(1889), the Royal Society

of the Humanities at

Lund (1918)
Publical Society for the

Publication of Manuscripts

concerning Scandinavian

History (1815), the Royal

Gustav Adolf Academy (1932)

The Royal Society of Naval

Sciences (1771), the Royal

Swedish Academy of War

Sciences (1796), The Royal

Swedish Academy of

Agriculture and Forestry

(1811), the Royal Swedish

Academy of Engineering

Sciences (1919)

The Royal Swedish Academy

of Fine Arts (1735), the Royal

Swedish Academy of Music

(1771)

Sources: http://www.kva.se; http://www.vetenskapssocietetenuppsala.se; http://www. fysiografen.se; http://www.kvvs.se; http://www.kvsu.se; http://www.skytteanskasamfundet. se; http://www.vitterhetsakad.se; http://www.svenskaakademien.se; http://www.

kungligasamfundet.se; http://www.kgaa.nu; http://www.khvsu.se; http://www.lu.se/lucat/ group/017080600; http://www.koms.se; http://www.kkrva.se; http://www.ksla.se; http://www. iva.se; http://www.konstakademien.se; and http://www.musakad.se. 
Prepublication version of chapter published in Linda Wedlin and Maria Nedeva (eds), Towards European Science: Dynamics and Change in Science Policy and Organization, 2015,

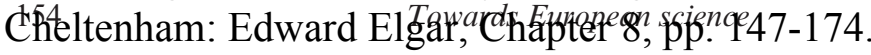

humanities. Others concentrate on either the natural sciences (like the Royal Society) or on the humanities, especially languages (like l'Académie française). There are also a number of academies oriented towards the arts (like l'Académie des beaux-arts). This diversity makes it appropriate to look more closely at the common characteristics of academies.

\section{CHARACTERISTICS OF ACADEMIES}

\section{Governance}

A basic question in relation to all types of organizations concerns the rules for their creation. For academies we may note that, in contrast to banking, where a charter is required to start a bank, there are in principle no formal barriers to entry. However, as is evident from the above, most of the old academies received official support from the monarch, manifested in the prefix "Royal". Some of them, like the Swedish Academy founded in 1786, were even founded on the initiative of the sovereign. Needless to say, the support from the head of state has been crucial for the trust in these institutions. And this trust and a related reputation are key variables for academies, as they are closed to an extent that is not found elsewhere. First, in comparison to corporations, they differ by not having any owners to which they are responsible. Second, in comparison to most associations they differ by having restricted membership. Of these two characteristics, the latter is particularly important for the building of reputation. New members are selected through cooptation by those who are already members. As a result academies and their members live in symbiosis: members gain in reputation by being elected into the academy, while academies gain in reputation by electing distinguished members of the academic community. And the latter is particularly important for their role in giving policy advice in general and the selection of experts for policy decisions in particular, a topic to which we will return below.

Traditionally, academies have in their statutes a specified number of members without consideration of age. As a result renewal can only occur at the decease of a member. However, in order to avoid petrification in modern times many academies have chosen to adopt new members as old members pass retirement age. Although this has the disadvantage of diluting the exclusivity of membership, it has the advantage of the academies gaining in reputation by adding well-reputed active academic scholars. Some academies, like the Royal Society, solve the renewal problem by adding a specified number of new members every year. ${ }^{17}$

In order to enhance their reputation academies also need to reflect the 


\section{Prepublication version of chapter published in Linda Wedlin and Maria Nedeva (eds), Towards European Science: Dynamics and Change in Science Policy and Organization, 2015,

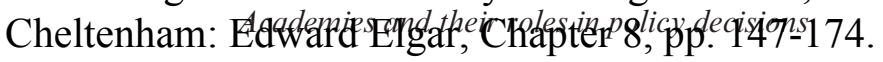

development of the wider scientific community. It is therefore important to guarantee that members from different disciplines are represented. In many academies this is achieved by a structure with different classes or divisions. Obviously, for old academies such structures have undergone considerable change over time. ${ }^{18}$

The fact that academies base their reputation on their members may also entail a problem when an elected member is suspected of misconduct in one way or another. A basic question is then whether a member can be excluded. The argument against this is obviously the risk that rules of exclusion may be used by those in power to expel their enemies and that it would be in conflict with the freedom of speech. Such rules do exist, however. For instance, Deutsche Akademie der Wissenschaften Leopoldina and the Royal Society have the following statement in their statutes, respectively: ${ }^{19}$

In the event of gross misconduct that is damaging to the Academy's reputation, a member can be expelled from the Academy.

If, in the opinion of Council, the conduct of any Fellow, Foreign Member or Honorary Fellow is injurious to the character or interests of the Society, Council, after due consideration and after giving the Fellow, Foreign Member or Honorary Fellow an opportunity to state his or her case in person, in writing or by representation, may require him or her to resign.

Since academies and their members live in symbiosis, the opposite of exclusion may also arise, that is, that an academy member does not like the activities or points of view of her or his academy. The most practical way for the individual to deal with this is of course to abstain from taking part in the activities of the academy, as academies, unlike organizations like Rotary, do not have rules of minimum participation. However, sometimes members like to distance themselves officially from the organization. Again, Deutsche Akademie der Wissenschaften Leopoldina has a rule in its statutes addressing this: ${ }^{20}$

A member may apply to retire from his or her duties for a limited or unlimited period. The Presidium decides on the acceptance of the application. All rights to vote and all duties then expire.

A counter example is the Swedish Academy, well known through its role as the institution that awards the Nobel Prize for Literature. In the wake of a conflict regarding the lack of support for the author Salman Rushdie after he received the Islamic fatwa, three of the 18 members declared that they wished to leave the Academy. As this was not granted, they choose to abstain from taking part in the meetings. ${ }^{21}$ 
Prepublication version of chapter published in Linda Wedlin and Maria Nedeva (eds), Towards European Science: Dynamics and Change in Science Policy and Organization, 2015,

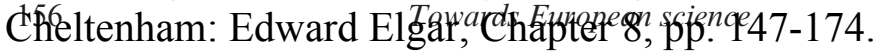

The above implies that academies can be expected to have considerable intellectual capital through the reputation of their members. However, in many cases their financial capital is not equally impressive. Membership fees are not very common. Donations occur but are often directed towards awards and other specific projects rather than the general financing of the organization. Corporate sponsoring as well as government support both create problems of credibility, since it may hamper the independence of the academy. At the very least, such economic support may lead to the suspicion that critical views may be suppressed or that the views expressed are related to economic transactions. ${ }^{22}$ However, academies may also have trouble activating their intellectual capital, since, as already mentioned, in most cases there are few obligations associated with academy membership. This is particularly important to note in relation to policy activities of academies, for which it is crucial to mobilize the star academicians.

\section{Missions}

A reading of mission statements of academies reveals in principle three basic tasks: (1) to promote science in various ways (among them to publish research results and to distribute prizes), (2) to provide expertise and advice, and (3) to foster international cooperation. ${ }^{23}$ For instance Deutsche Akademie der Wissenschaften Leopoldina declares that: ${ }^{24}$

Its mission is that of promoting science in national and international cooperation, traditionally "for the benefit of humankind and nature".

For this purpose, it runs academic events, appoints commissions, and publishes the results obtained. It awards honours and prizes and promotes junior scientists.

With its appointment as National Academy of Sciences, the Leopoldina officially assumes the representation of German scientists in the international committees in which other Academies of Sciences are represented, and it contributes to the science-based consulting of the public and politics. This does not affect the missions or activities of the German Research Foundation, the Max Planck Society or the other members of the alliance.

And similar statements can be found for other academies such as the Royal Society and l'Académie des sciences. ${ }^{25}$

In terms of the first task (to promote science in various ways), academies have over time been active to varying degrees with their own research institutes. This has particularly been the case in Central and Eastern Europe, but also to some extent in countries like Austria, the Netherlands and Sweden. ${ }^{26}$ However, this task has also to a large extent entailed the strengthening of the influence of the sciences in society, that 
Prepublication version of chapter published in Linda Wedlin and Maria Nedeva (eds), Towards European Science: Dynamics and Change in Science Policy and Organization, 2015,

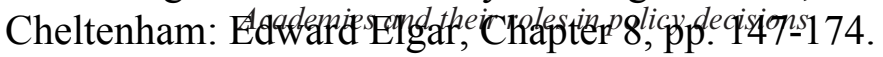

is, to be active regarding policy for science and science for policy. In both cases, however, academies may find it difficult to provide clear-cut opinions, as, like all academic institutions, academies host members with many different views. Therefore, when it comes to the second task (to provide expertise and advice) it is often individual members who act rather than the organization. However, in so doing, their relationship to prestigious academies is an asset that means that they are listened to. Academies have in this way been instrumental in the identification of scientific elites. This has increasingly been the case in quality assessments.

The third task (to foster international cooperation) has obviously become more important in modern society with its increasing international links between individuals as well as organizations. An important feature in this context is meta-organizations (Ahrne and Brunsson 2008), that is, organizations whose members are organizations rather than individuals. Since such organizations have become increasingly important for the interaction between academies and society, in the next section we will look more closely at their development, before we turn to the policy activites of European academies.

\section{ACADEMIES IN INTERNATIONAL COOPERATION}

International cooperation has traditionally been an important task for academies, particularly as manifested through the exchange of publications and scientific results. However, with the growth of the number of academies an increasing formalization of international cooperation has taken place through the foundation of meta-organizations. A few of them were created in the twentieth century (Table 8.3), while a large number emerged in the present century (Table 8.4).

Among the meta-organizations of academies, the first appears to have been the International Association of Academies (IAA), founded in 1899 and dissolved after the First World War in $1919 .{ }^{27}$ In its place two other organizations were created: Union Académique Internationale (UAI) for the humanities and the International Research Council (IRC) for the sciences (Campbell 1920). In 1931 the latter was turned into the still existing International Council for Science (ICSU), which presently has a membership of 120 national scientific bodies of 140 nationalities and 31 International Scientific Unions. ${ }^{28}$

The second half of the twentieth century saw the creation of three metaorganizations of academies (see again Table 8.3): International Foundation for Science (IFS) in 1972, InterAcademy Panel on International Issues (IAP) in 1993 and All European Academies (ALLEA) in 1994. Of these 
Prepublication version of chapter published in Linda Wedlin and Maria Nedeva (eds), Towards European Science: Dynamics and Change in Science Policy and Organization, 2015, dheltenham: Edward Elgar,,

Table 8.3 Early meta-organizations of academies

\begin{tabular}{|c|c|c|c|}
\hline Year & Name & Mission & Members \\
\hline 1899-1919 & $\begin{array}{l}\text { International } \\
\text { Association } \\
\text { of Academies } \\
\text { (IAA) }\end{array}$ & $\begin{array}{l}\text { To link various academies } \\
\text { around the world }\end{array}$ & $\begin{array}{l}\text { Specific } \\
\text { membership not } \\
\text { available }\end{array}$ \\
\hline 1919 & $\begin{array}{l}\text { Union } \\
\text { Académique } \\
\text { Internationale } \\
\text { (UAI) }\end{array}$ & $\begin{array}{l}\text { To promote the advancement } \\
\text { of knowledge, development } \\
\text { of scientific exchanges and } \\
\text { initiatives of its academies }\end{array}$ & $\begin{array}{l}\text { About } 100 \\
\text { academies of } 60 \\
\text { nationalities in the } \\
\text { humanities and the } \\
\text { social sciences }\end{array}$ \\
\hline 1919-1931 & $\begin{array}{l}\text { International } \\
\text { Research } \\
\text { Council (IRC) }\end{array}$ & $\begin{array}{l}\text { (a) To coordinate } \\
\text { international efforts in the } \\
\text { different branches of science } \\
\text { and its applications, (b) to } \\
\text { initiate the formation of } \\
\text { international Associations } \\
\text { or Unions, (c) To direct } \\
\text { international scientific activity } \\
\text { in subjects [outside] existing } \\
\text { international associations, (d) } \\
\text { to enter through the proper } \\
\text { channels into relation with the } \\
\text { Governments }\end{array}$ & $\begin{array}{l}\text { Specific } \\
\text { membership not } \\
\text { available }\end{array}$ \\
\hline 1931 & $\begin{array}{l}\text { International } \\
\text { Council for } \\
\text { Science (ICSU) }\end{array}$ & $\begin{array}{l}\text { To strengthen international } \\
\text { science for the benefit of } \\
\text { society }\end{array}$ & $\begin{array}{l}120 \text { national } \\
\text { scientific } \\
\text { bodies of } 140 \\
\text { nationalities and } \\
31 \text { International } \\
\text { Scientific Unions }\end{array}$ \\
\hline 1972 & $\begin{array}{l}\text { International } \\
\text { Foundation for } \\
\text { Science (IFS) }\end{array}$ & $\begin{array}{l}\text { To contribute towards } \\
\text { strengthening the capacity } \\
\text { of developing countries to } \\
\text { conduct relevant and high } \\
\text { quality research on the } \\
\text { sustainable management } \\
\text { of biological and water } \\
\text { resources }\end{array}$ & $\begin{array}{l}\text { IFS has } 135 \\
\text { affiliated } \\
\text { organisations in } 86 \\
\text { countries, mainly } \\
\text { in the developing } \\
\text { world }\end{array}$ \\
\hline 1993 & $\begin{array}{l}\text { InterAcademy } \\
\text { Panel on } \\
\text { International } \\
\text { Issues (IAP) }\end{array}$ & $\begin{array}{l}\text { IAP is a global network of } \\
\text { the world's science academies } \\
\text { [with the] goal to help } \\
\text { member academies work } \\
\text { together to advise citizens } \\
\text { and public officials on the } \\
\text { scientific aspects of critical } \\
\text { global issues }\end{array}$ & 105 academies \\
\hline
\end{tabular}


Prepublication version of chapter published in Linda Wedlin and Maria Nedeva (eds), Towards European Science: Dynamics and Change in Science Policy and Organization, 2015,

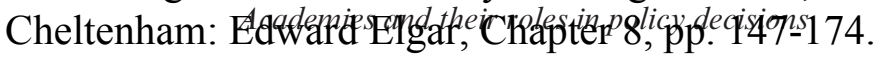

Table 8.3 (continued)

\begin{tabular}{|c|c|c|c|}
\hline Year & Name & Mission & Members \\
\hline 1993 & $\begin{array}{l}\text { Federation } \\
\text { of European } \\
\text { Academies } \\
\text { of Medicine } \\
\text { (FEAM) }\end{array}$ & $\begin{array}{l}\text { To promote cooperation } \\
\text { between the national } \\
\text { Academies of Medicine; and } \\
\text { to extend to the political and } \\
\text { administrative authorities } \\
\text { of EU the advisory role on } \\
\text { matters concerning medicine } \\
\text { and public health }\end{array}$ & $\begin{array}{l}13 \text { academies in } \\
\text { EU members states }\end{array}$ \\
\hline 1994 & $\begin{array}{l}\text { All European } \\
\text { Academies } \\
\text { (ALLEA) }\end{array}$ & $\begin{array}{l}\text { (1) To promote cooperation } \\
\text { between Member-academies } \\
\text { through exchange of } \\
\text { information and experience, } \\
\text { and (2) to collaborate in } \\
\text { giving advice on policy issues } \\
\text { to particular audiences }\end{array}$ & $\begin{array}{l}52 \text { academies in } \\
\text { more than } 40 \\
\text { countries from the } \\
\text { Council of Europe } \\
\text { region }\end{array}$ \\
\hline
\end{tabular}

Sources: $\quad$ Science (1904), Alter (1980), http://www.uai-iua.org; http://www.icsu.org; http:// www.ifs.se; http://www.interacademies.net; http://www.feam.eu.com; http://www.allea.org.

IFS is oriented towards the developing world, IAP with its 100 members aims at giving advice "on the scientific aspects of global issues", while ALLEA brings together some 50 European academies (see further below).

While the twentieth century brought about the foundation of a number of organizations with academies as members, the first decade of the twenty-first century signified an even larger expansion of such organizations (cf. Table 8.4). Many of the new meta-organizations, like the European ALLEA, have involved the gathering of academies of a particular region for cooperation: Association of Academies of Sciences in Asia (AASA; 2000), the Caribbean Scientific Union (CCC; 2000), Network of African Science Academies (NASAC; 2001), InterAmerican Network of Academies of Sciences (IANAS; 2004), Network of Academies of Science in the Islamic Countries (NASIC; 2004) and Euro-Mediterranean Academic Network (EMAN; 2010). Another phenomenon is the bringing together of specialized academies: Federation of European Academies of Medicine (FEAM; 1993), InterAcademy Medical Panel (IAMP; 2000) and International Council of Academies of Engineering and Technological Sciences (CAETS; 2000). Finally, two of the twenty-first century organizations were particularly oriented toward policy-making: InterAcademy Council (IAC; 2000) and European Academies Science Advisory Council 
Prepublication version of chapter published in Linda Wedlin and Maria Nedeva (eds), Towards European Science: Dynamics and Change in Science Policy and Organization, 2015, difeltenham: Edward Elgar,,

Table 8.4 Meta-organizations of academies founded in the 21 st century

\begin{tabular}{|c|c|c|c|}
\hline Year & Name & Mission & Members \\
\hline 2000 & $\begin{array}{l}\text { InterAcademy } \\
\text { Council (IAC) }\end{array}$ & $\begin{array}{l}\text { To provide advice on the } \\
\text { scientific, technological } \\
\text { and health aspects of } \\
\text { issues of global, regional } \\
\text { or national importance } \\
\text { to intergovernmental } \\
\text { organizations, to other } \\
\text { international bodies and } \\
\text { institutions, to national } \\
\text { governments and to other } \\
\text { decision-makers }\end{array}$ & $\begin{array}{l}\text { About } 20 \\
\text { academies } \\
\text { with global } \\
\text { representation }\end{array}$ \\
\hline 2000 & $\begin{array}{l}\text { InterAcademy } \\
\text { Medical Panel } \\
\text { (IAMP) }\end{array}$ & $\begin{array}{l}\text { To strengthen the role of } \\
\text { all academies to alleviate } \\
\text { the health burdens of the } \\
\text { world's poorest people; } \\
\text { build scientific capacity } \\
\text { for health; and provide } \\
\text { independent scientific }\end{array}$ & $\begin{array}{l}\text { A network of } \\
\text { the world's } \\
\text { academies of } \\
\text { Medicine, Science, } \\
\text { Engineering and } \\
\text { others having } \\
\text { Medical members }\end{array}$ \\
\hline 2000 & $\begin{array}{l}\text { International Council } \\
\text { of Academies of } \\
\text { Engineering and } \\
\text { Technological } \\
\text { Sciences (CAETS). }\end{array}$ & $\begin{array}{l}\text { To promote engineering } \\
\text { sciences and provide } \\
\text { expertise in international } \\
\text { cooperation }\end{array}$ & $\begin{array}{l}21 \text { engineering } \\
\text { academies } \\
\text { world-wide }\end{array}$ \\
\hline 2000 & $\begin{array}{l}\text { Association of } \\
\text { Academies of } \\
\text { Sciences in Asia } \\
\text { (AASA) }\end{array}$ & $\begin{array}{l}\text { To establish an } \\
\text { international } \\
\text { interdisciplinary network } \\
\text { for scientific and } \\
\text { technological cooperation, } \\
\text { and to play a pivotal role } \\
\text { in promoting cooperation } \\
\text { for the development of } \\
\text { science and technology in } \\
\text { the region }\end{array}$ & $\begin{array}{l}27 \text { academies } \\
\text { with science } \\
\text { and technology } \\
\text { interests }\end{array}$ \\
\hline 2000 & $\begin{array}{l}\text { The Caribbean } \\
\text { Scientific Union } \\
(\mathrm{CCC})\end{array}$ & $\begin{array}{l}\text { To integrate, consolidate } \\
\text { and promote the } \\
\text { Academies of the Wider } \\
\text { Caribbean region and } \\
\text { their impact on the } \\
\text { strengthening of scientific } \\
\text { communities there, and to } \\
\text { increase their impact on } \\
\text { local communities }\end{array}$ & $\begin{array}{l}\text { Academies in the } \\
\text { Caribbean region }\end{array}$ \\
\hline
\end{tabular}


Prepublication version of chapter published in Linda Wedlin and Maria Nedeva (eds), Towards European Science: Dynamics and Change in Science Policy and Organization, 2015,

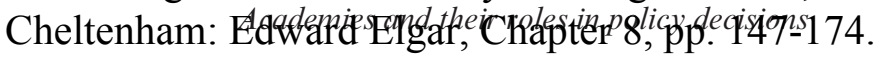

Table 8.4 (continued)

\begin{tabular}{|c|c|c|c|}
\hline Year & Name & Mission & Members \\
\hline 2001 & $\begin{array}{l}\text { European Academies } \\
\text { Science Advisory } \\
\text { Council (EASAC) }\end{array}$ & $\begin{array}{l}\text { To provide authoritative } \\
\text { reports and assessments on } \\
\text { scientific topics relevant to } \\
\text { European policy needs }\end{array}$ & $\begin{array}{l}26 \text { national science } \\
\text { academies of } \\
\text { every EU Member } \\
\text { State, Academia } \\
\text { Europaea and } \\
\text { ALLEA }\end{array}$ \\
\hline 2001 & $\begin{array}{l}\text { Network of African } \\
\text { Science Academies } \\
\text { (NASAC) }\end{array}$ & $\begin{array}{l}\text { To act as an independent } \\
\text { African forum that brings } \\
\text { together the nine merit- } \\
\text { based academies of science } \\
\text { in the continent }\end{array}$ & $\begin{array}{l}\text { Nine African } \\
\text { academies }\end{array}$ \\
\hline 2004 & $\begin{array}{l}\text { InterAmerican } \\
\text { Network of } \\
\text { Academies of } \\
\text { Sciences (IANAS) }\end{array}$ & $\begin{array}{l}\text { To support cooperation } \\
\text { towards the strengthening } \\
\text { of science and technology } \\
\text { as a tool for advancing } \\
\text { research and development, } \\
\text { prosperity and equity in } \\
\text { the Americas }\end{array}$ & $\begin{array}{l}\text { A regional network } \\
\text { of Academies of } \\
\text { Sciences }\end{array}$ \\
\hline 2004 & $\begin{array}{l}\text { Network of } \\
\text { Academies of } \\
\text { Science in the Islamic } \\
\text { Countries (NASIC) }\end{array}$ & $\begin{array}{l}\text { To catalyze the } \\
\text { development of } \\
\text { collaborative programs } \\
\text { among OIC member } \\
\text { countries }\end{array}$ & $\begin{array}{l}17 \text { academies in } \\
\text { Islamic countries }\end{array}$ \\
\hline 2010 & $\begin{array}{l}\text { Euro-Mediterranean } \\
\text { Academic Network } \\
\text { (EMAN) }\end{array}$ & $\begin{array}{l}\text { To promote the growth } \\
\text { and coordination of a } \\
\text { Mediterranean science area }\end{array}$ & $\begin{array}{l}\text { Academies of } \\
\text { science of the } \\
\text { Mediterranean } \\
\text { countries }\end{array}$ \\
\hline
\end{tabular}

Sources: http://www.interacademycouncil.net; http://www.iamp-online.org; http://www. caets.org; http://www.aasa-net.org; http://www.interacademies.net; http://www.easac.eu; http://www.nasaconline.org; http://www.interacademies.net.

(EASAC; 2001). Their policy orientation is evident from their mission statements: ${ }^{29}$

The IAC shall provide advice on the scientific, technological and health aspects of issues of global, regional or national importance to intergovernmental organizations, to other international bodies and institutions, to national governments and to other decision-makers.

The main business of the Council shall be to provide authoritative reports and assessments on scientific topics relevant to European policy needs. 
Prepublication version of chapter published in Linda Wedlin and Maria Nedeva (eds), Towards European Science: Dynamics and Change in Science Policy and Organization, 2015, direltenham: Edward Elgarardnapter 8, spipnqe47-174.

Interest in taking part in policy-making appears to be shared to varying degrees by the other meta-organizations mentioned above. This in turn seems to represent a change in the role of these organizations. While at the beginning of the twentieth century they were basically oriented towards research projects, policy-making has become increasingly important for them. This in turn can be explained by the increasing role of research in modern societies and the development of various types of lobbying and communication efforts. ${ }^{30}$

\section{ACADEMIES IN EUROPEAN POLICY-MAKING}

\section{Global Transnational Organizations}

It should be evident from the previous section that there are a multitude of global organizations that bring academies together for cooperation. They are all very important for the relationship between scientific communities and society. Many European academies belong to several of these. However, although the most general of them (ICSU and IAP) have their offices in Europe (Paris and Trieste, respectively), the formal European influence is limited. Only about one third of the ICSU Excutive Board and about one fifth of the IAP Exective Committee are Europeans, which is not remarkable since the two organizations are global in orientation. ${ }^{31}$ Needless to say these two organizations may nevertheless have an impact on European policy decisions through projects and initiatives on global issues such as climate change, ecosystems, biodiversity, and so on. ICSU thus declares that it is particularly promoting closer relationships between its historically strong members in North America and Europe, on the one hand, and less developed countries, on the other. ${ }^{32}$ IAP also has clear European connections by having among its partners two organizations that appear particularly important for the development of European policy-making, that is, ALLEA and EASAC. ${ }^{33}$

\section{European Transnational Organizations}

Discussions regarding the formation of an organization for European academies started in the early 1990s after the fall of the Berlin Wall in 1989. On the initiative of l'Académie française, the Royal Society, the Royal Swedish Academy of Sciences and the Royal Netherlands Academy of Arts and Sciences, ALLEA was officially launched in $1994 .{ }^{34}$ The idea was to raise the mission of the national academies to the European level. It started out as a clearinghouse for member academies at the Royal 
Prepublication version of chapter published in Linda Wedlin and Maria Nedeva (eds), Towards European Science: Dynamics and Change in Science Policy and Organization, 2015,

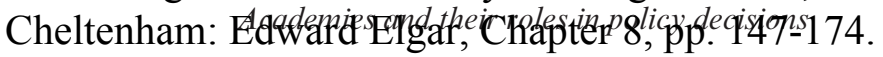

Society. It got a permanent office at the Dutch Academy in 2000 through support from the Dutch government and the Royal Netherlands Academy of Arts and Sciences (KNAW), and moved in 2012 to Berlin and the Berlin-Brandenburg Academy of Sciences and Humanities (the academy founded by Leibniz). Throughout its existence ALLEA has focussed on what Engelbrecht and Mann (2011: 19) label policy for science rather than science for policy, that is, on conditions for European research. ${ }^{35}$ This has been manifested through standing committees on "Science and Ethics" and "Intellectual Property Rights" as well as working groups on "Research cooperation", "Science and the media", "Privacy in the information society", "Evaluation for science", and "Science education". ALLEA has also been an active proponent of the European Research Council as well as a partner in dialogues with the European Commission regarding the Framework Programmes and related matters. ALLEA differs from most other of the transnational meta-organizations of academies by having academies with different orientations as its members. ${ }^{36}$

While ALLEA has been oriented towards policy for science, EASAC, the European Academies Science Advisory Council, is providing science input to policy. Founded in 2001 by national science academies of the EU Member States and Academia Europaea, it is also a more narrow organization in terms of discipline representation. Thus while the board of ALLEA is constituted by a fairly balanced distribution of members from the natural sciences and medicine, on the one hand, and the humanities and social sciences on the other ( 55 per cent vs. 45 per cent), the Council of EASAC is dominated by the former disciplines (93 per cent vs. 7 per cent). EASAC conducts programmes in three fields: energy, biosciences and environment, each with a steering panel and a secretary. As of 2010 the Secretariat is located at Deutsche Akademie der Wissenschaften Leopoldina. In order to facilitate interaction with EU politicians, which is crucial for its activities, EASAC has set up an office in Brussels sponsored by the Belgian academy the Royal Academies for Science and the Arts. ${ }^{37}$

In addition to ALLEA and EASAC, it is appropriate to mention two other organizations on the European scene: the European Science Foundation (ESF), and Academia Europaea. The first of these was founded in 1974 with a mixed membership of European academies and research councils. As the research councils had the financial resources, they became more dominant in ESF than the academies, and therefore in 2008 a joint ALLEA-ESF workshop was organized to strengthen the role of the academies. However, developments have gone in another direction. As a consequence, several European academies left ESF, and the activities of ESF have gradually been transferred to the new organization Science Europe, "an association of European Research Funding 
Prepublication version of chapter published in Linda Wedlin and Maria Nedeva (eds), Towards European Science: Dynamics and Change in Science Policy and Organization, 2015,

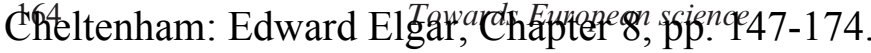

Organisations (RFO) and Research Performing Organisations (RPO), based in Brussels". 38

While the organizations discussed so far are meta-organizations of academies, Academia Europaea, mentioned above, is based on individual membership. However, it nevertheless has ambitions to play a role in policy-making. In its mission statement it thus declares that: ${ }^{39}$

[It will make] recommendations to national governments and international agencies concerning matters affecting science, scholarship and academic life in Europe [and that it will endeavour to promote] a better understanding among the public at large of the benefits of knowledge and learning, and of scientific and scholarly issues which affect society, its quality of life and its standards of living.

Academia Europaea, like ALLEA, has in comparison to EASAC a stronger representation for the humanities and the social sciences in its board: 41 per cent. ${ }^{40}$ At the same time it can be noted that Academia Europaea was a founding member of EASAC. ${ }^{41}$

All in all, it is very easy to agree with the statement by Staffan Helmfrid at the ALLEA meeting in Stockholm 1992: "There is certainly no lack of organizations for scientific cooperation and exchange in Europe". ${ }^{42}$

\section{National Academies}

European academies have thus been able to influence policy decisions through ALLEA and EASAC, and earlier to some extent through ESF. However, the European academies have also played a policy role through their own activities. This can be demonstrated by the three oldest European academies of science, that is, Deutsche Akademie der Wissenschaften Leopoldina, the Royal Society, and l'Académie des sciences. Far from being ivory towers, they have long interacted with society at large through publications and other expressions of views.

The policy advice of Deutsche Akademie der Wissenschaften Leopoldina is mainly directed towards issues such as "climate change, energy supply, disease control and health, demographic change, global economic systems, conflict research and the use of natural resources". And, there are reasons to believe that the advice of the academy is listened to. According to its web-page: ${ }^{43}$

Leopoldina's voice is respected. For example, its statement on the energy and research policy implications of the nuclear disaster in the Japanese prefecture of Fukushima in spring 2011 impacted on the work and the recommendations of Chancellor Angela Merkel's Ethics Commission on a Safe Energy Supply. Another statement published in 2011 focusing on preimplantation genetic 


\section{Prepublication version of chapter published in Linda Wedlin and Maria Nedeva (eds), Towards European Science: Dynamics and Change in Science Policy and Organization, 2015,

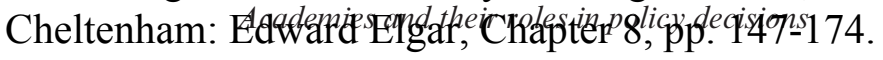

diagnosis (PGD) met with great interest among the members of the German Bundestag and was widely discussed in the media and in the society.

Due to the significance of the German economy and its central geographical position within the European Union we can also expect that the views of the academy also have an impact outside Germany. National and international trust based on the reputation of the academy probably contributes to this, but they would seem to be more specifically based on the four specific guidelines for the policy advice of the academy: 44

- Transparent working methods that are documented in a reproducible way.

- Open and unbiased design of advisory process through inclusion of different disciplines.

- Statements that are developed independently of any economic and political interests giving recommendations on how to approach specific problems facing society.

- Clear presentation and broad dissemination of recommendations in order to encourage public debate.

The policy work is undertaken in working groups and standing committees. In addition, international cooperation constitutes a significant part of the policy work of the German academy. Deutsche Akademie der Wissenschaften Leopoldina thus has links to six of the organizations listed in Tables 8.3 and 8.4: ALLEA, EASAC, FEAM, IAC, IAP and IAMP. ${ }^{45}$ In addition to hosting the EASAC Head Office, as mentioned above, the links to EASAC are also manifested by representation by Leopoldina members on EASAC steering panels and working groups as well as a great number of meetings at the academy. ${ }^{46}$

The Royal Society, for its part, can claim that its first scientific advice to policy-makers (on the state of Britain's forests) appeared as early as $1664 .{ }^{47}$ And, some 350 years later these activities go on in various forms, among which the Science Policy Centre, founded in 2010, constitutes a basic platform. It deals with four flagship themes: sustainability, diplomacy, innovation and governance. ${ }^{48}$ Again we can see the ambitions to strengthen the position of science in society by giving advice regarding urgent problems and by providing a better understanding for the role of science. It is particularly worth noting that there are few geographic limitations in the programme. Most problems are global, and in addition we can note that the Royal Society expresses a particular interest in alliances of academies, Islamic world science and innovation as well as capacity building in Africa. As a result, the Royal Society can claim that their "spheres of influence 
Prepublication version of chapter published in Linda Wedlin and Maria Nedeva (eds), Towards European Science: Dynamics and Change in Science Policy and Organization, 2015, dhíltenham: Edward Elgarardnapter 8, spipnqe47-174.

include decision makers in Westminster and Whitehall; business leaders; research funders and bodies such as the European Commission, OECD, World Bank and UN agencies". 49

As far as the French l'Académie des sciences is concerned, one of its five missions is to ensure "a dual role of expertise and advice". This is accomplished through: ${ }^{50}$

Arbitrating among possible scientific and technological options [...] within the remit of elected politicians, but they must be enabled to do so, on sound, reasoned bases. The Academy is called upon by public authorities to intervene as an expert, advisory body; it can likewise self-commission studies on similar questions, as it sees fit. Its conclusions are duly published: in reports, in advice notes and recommendations; in the form of expertise.

In 2010-2011 these efforts resulted in 14 reports on topics like the Fukishima accident, education, vaccination, climate changes, and space research. ${ }^{51}$ Like its British sister academy the French one is trying to stimulate a dialogue between researchers and politicians. This is accomplished through the programme "Pairing between Members of the French Parliament, Members of the Académie des sciences and young scientists". ${ }^{52}$ Also, like the Royal Society, l'Académie des sciences aims at fostering international collaboration. Means for this are constituted by membership or participation in international organizations, bilateral or multilateral cooperation and partnerships with developing countries. In terms of the international organizations l'Académie des sciences particularly points to the International Council for Science (ICSU), the InterAcademy Panel on International Issues (IAP), the European Academies Science Advisory Council (EASAC) and the All European Academies (ALLEA). ${ }^{53}$

In addition to the involvement of the national academies in policymaking we should also note the role of individual academy members from the different nations. This can be demonstrated by an analysis of the links between European academies and the 22 members of the governing body of the European Research Council (ERC) in 2013. Among them two thirds (15) are elected members of Academia Europaea, and together they have 40 elections to other academies, among them the Royal Society and the National Academy of Sciences. ${ }^{54}$ So even if academies are not directly represented in the ERC, they have close links through their members. It could also be argued that through their selection processes the academies have been helpful by signalling excellence among their academic compatriots to ERC recruiters. 


\section{Prepublication version of chapter published in Linda Wedlin and Maria Nedeva (eds), Towards European Science: Dynamics and Change in Science Policy and Organization, 2015,

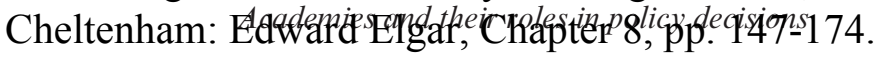

\section{Concluding Remarks}

The above implies that we have been able to identify considerable activities from European academies in policy-making. This is accomplished both through meta-organizations, like ALLEA and EASAC, and directly through initiatives of national academies. In addition, individual academy members tend to be elected to hold significant posts on the basis of the reputation gained from academy membership. All this may indicate that the influence of academies has increased and will increase over time. However, it is important also to point out that the environment of the academies has changed with the passage of time. The field of higher education and research has undergone strong growth in most countries, and many actors are trying to make their voice heard. In addition, there are indications that academic excellence is not always appreciated in the selection of academic leaders (Engwall 2014a). At the same time it appears important to keep in mind that selectivity, which is a key feature of academy membership, may be even more important for individuals in a world crowded with scientists.

\section{CONCLUSIONS}

Our analysis of the role of academies in policy-making has provided a number of conclusions:

1. The academy as an organizational form, emerging from Renaissance Italy, has been successfully adopted all over the globe, before the twentieth century particularly in European countries, later spreading to Asia and the Americas, and since the 1950s also to Africa.

2. Academies have special opportunities to take part in policy-making, as they are closed organizations to which members are elected on the basis of their scholarly reputation. In this way academies and their members live in symbiosis: members acquire reputation through membership and academies gain in reputation from their members.

3. Our analysis of mission statements has demonstrated that academies basically focus on three tasks: (1) to promote science in various ways, (2) to provide expertise and advice, and (3) to foster international cooperation.

4. In terms of the involvement of academies in policy-making it is important to make a distinction between (1) policy for science and (2) science for policy. In the former case academies are involved in discussions regarding the conditions for scientific work, and in the latter case they offer input from their expertise for other significant political decisions. 
Prepublication version of chapter published in Linda Wedlin and Maria Nedeva (eds), Towards European Science: Dynamics and Change in Science Policy and Organization, 2015, direltenham: Edward Elgarardnapter 8, spipnqe47-174.

5. The past hundred years have entailed, not only the foundation of a considerable number of academies, but also the creation of a large number of meta-organizations of academies, that is, organizations for transnational cooperation between various national academies.

6. In policy-making we have been able to identify efforts both through the transnational organizations and also through national academies, particularly those based in the major European countries. We have also noted that academies have indirect influence through their members, who are recruited to important positions with policy implications.

7. Finally, it is appears fair to conclude that the world of academies is characterized by competition. This has been evident in the development of the academies themselves with many different intitiatives over time. This appears to be equally true, or perhaps even more so, regarding the meta-organizations of academies, for which there are a number of competing alternatives. Sometimes, as in the case of ALLEA and EASAC, this has led to a division of labour.

After these conclusions it may be appropriate to speculate somewhat on the future role of academies in policy-making. It is obvious that they are highly likely to continue to express their views on the policy for science, since the strengthening of the influence of science in society is a basic concern for all academies. To what extent they will be listened to on this matter is another question. Even if, as mentioned by way of introduction, science policy has tended to become the modern defence policy, excessively high expectations on deliveries that do not materialize may constitute a risk that politicians will become less sensitive to the arguments of academies.

Then, in terms of science for policy, there are also reasons to believe that academies will continue to be active. It is a question of communicating research results to decision-makers and contributing to a better world. However, as already indicated above, academies are not monoliths and, due to the uncertainty associated with research, are not always characterized by consensus. This may be difficult to understand for outsiders, who therefore may prefer to talk to commercial consultants rather than academies. It is important that academies be aware of this competition.

For both types of advisory roles we may expect academies to increase their communication efforts by adding new staff for that purpose. Such a development is in line with a general trend in society entailing that communication activities - in the form of persuasion, promotion and protection - have become increasingly common (Engwall 2014b). This has been observed for corporations but also for other institutions such as universities (Engwall 2008). And, academies cannot be expected to be an 


\section{Prepublication version of chapter published in Linda Wedlin and Maria Nedeva (eds), Towards European Science: Dynamics and Change in Science Policy and Organization, 2015,

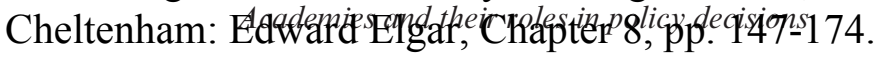

exception to this general trend. The followers of Plato are therefore likely to express their views on policy issues increasingly through various channels.

\section{NOTES}

1. I am grateful for valueable comments on an earlier draft from Pieter Drenth, Jüri Engelbrecht, Jürgen Mittelstrass, Helga Nowotny, Stig Strömholm, and Sten Widmalm.

2. See also Drenth (2006, pp. 183-95).

3. “Longtemps, la puissance d'une nation s'est mesurée à celle de son armée. Aujourd'hui, elle s'évalue plutôt à son potentiel scientifique." (Le Monde, 2003, April 8, p. 1).

4. Since 1832 they are part of l'Institut de France, which also includes two other French academies created in 1795: l'Académie des beaux-arts and l'Académie des sciences morales et politiques.

5. In terms of age, it is true that the Italian Accademia dei Lincei was founded as early as 1603. However, it was closed down in 1651 and reestablished in 1875. (http://www.lincei. it/modules.php?name $=$ Content $\&$ pa $=$ showpage $\&$ pid $=21)$.

6. On the early period of this academy, see further Engwall (2012). The internationally better-known Royal Swedish Academy of Sciences was founded in 1739.

7. http://www.amphilsoc.org/. For further information on the development of the academies in the eighteenth century, see McClellan (1985).

8. http://mta.hu, http://www.hazu.hr, http://pau.krakow.pl and http://www.sanu.ac.rs. As was pointed out to me by Helga Nowotny, under Communism the Eastern Europe the Academy Presidents became politically very important, since the academies were the only institutions for research. See also Proukakis and Katsaros (1997).

9. http://www.royalsociety.org.nz/organisation/; http://www.royalsocietysa.org.za; http:// rsc-src.ca; http://www.anc-argentina.org.ar; http://www.abc.org.br; and http://www. accefyn.org.co/sp/history.htm.

10. Among more recent supplementary academies it is particularly worth mentioning the founding of young academies in Austria, Germany, the Netherlands, Poland and Sweden (Engelbrecht and Mann, 2011, p.32). Since December 2012 the Young Academy of Europe organizes ERC starting grant holders (http://yacadeuro.org/about-yae.htm).

11. DeGeer (1978, pp. 117-19) and http://www.caets.org.

12. http://www.ae-info.org/. See also Burgen (2009) and European Review (2011).

13. Its statutes were approved by the Belgian King in 2003 (http://www.eurasc.org/aboutus/ statutes.asp). Before that the whole organization was seriously questioned in an article in Nature (Adam, 2002).

14. http://www.interacademies.net/About/Committees/15444/TWAS.aspx.

15. http://www.interacademies.net/Academies/11798/11025/IAS.aspx.

16. http://www.worldacademy.org.

17. The Royal Society thus every year invites members to propose new members by 30 September. Candidates are then reviewed through a sophisticated screening procedure including reference letters from members of the Royal Society and other academies. And, at the end of the process 44 fellows, eight foreign members and one honorary fellow are elected (http://royalsociety.org/uploadedFiles/Royal_Society_Content/aboutus/fellowship/130810_ElectionProcess.pdf).

18. Cf. e.g. Frängsmyr (1989) for the development of the class structure within the Royal Swedish Academy of Sciences.

19. http://www.leopoldina.org/en/about-us/presidium-boards/statutes/, third paragraph and http://royalsociety.org/uploadedFiles/Royal_Society_Content/about-us/governance/Statutes.pdf, Chapter IV.

20. http://www.leopoldina.org/en/about-us/presidium-boards/statutes/, third paragraph. 


\section{Prepublication version of chapter published in Linda Wedlin and Maria Nedeva (eds), Towards European Science: Dynamics and Change in Science Policy and Organization, 2015,

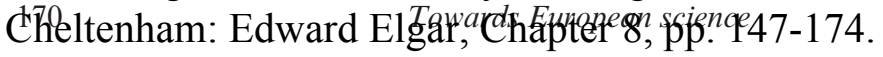

21. Two of them boycotted the Academy completely, while the third one had some limited contacts with the Academy.

22. As was pointed out to me by Pieter D. J. Drenth, academy members in many Eastern European academies receive a yearly salary (often on top of their professorial salary). Needless to say, this creates additional problems, with respect to the budget as well as the selection of new members.

23. For discussions of these missions, see Drenth (2006, pp. 183-251).

24. http://www.leopoldina.org/en/about-us/presidium-boards/statutes. For a discussion of the role of academies, see the speech at Deutsche Akademie der Wissenschaften Leopoldina by Jürgen Mittelstrass (2010).

25. See http://royalsociety.org/about-us and http:/www.academie-sciences.fr/en/mission. htm. On the role of the French academy of sciences, see Grunberg-Manago (1997).

26. In terms of Sweden, the Royal Swedish Academy of Sciences has during the last decade transferred a considerable part of their research facilities to universities.

27. Science (1904) and Alter (1980).

28. http://www.icsu.org/about-icsu/about-us.

29. http://www.interacademycouncil.net/23450/24788/24801.aspx and http://www.easac.eu/ about-easac/easac-statutes.html, respectively.

30. Some, like Quére (2010), also argue that it is a responsibility of academies to engage with society.

31. Calculations based on the information provided at http.//www.icsu.org and http://www. interacademies.net.

32. $\operatorname{ICSU}(2011$, pp. 36-7).

33. http://www.interacademies.net/About/18456.aspx.

34. On the contributions of ALLEA, see Drenth (2006, pp. 231-8).

35. Cf. e.g. All-European-Academy Meeting (1993).

36. Engelbrecht and Mann (2011, pp. 18-20) and http://www.allea.org/Pages/ALL/4/982. bGFuZz1FTkc.html.

37. http://www.easac.eu/home.html and http://www.leopoldina.org/en/international-issues/ ihttp://www.ae-info.org/nternational-academy-associations/easac/.

38. http://www.esf.org, Engelbrecht and Mann (2011, pp. 31-2), Clery (2011), ESF (2009), http://www.esf.org/esf-today/recent-developments.html and http://www.scienceeurope. org/.

39. http://www.ae-info.org/ae/Acad_Main/About_us/Mission_Statement.

40. The corresponding figure for IAP Executive Committee is 0 per cent, for the ICSU Exective Board 22 per cent and for ERC Scientific Council 23 per cent.

41. http://www.acadeuro.org

42. All-European-Academy Meeting (1993, p. 8).

43. http://www.leopoldina.org/en/policy-advice/science-for-politics-and-society/. Note that it was not until 2007 that the Leopoldina academy became the German national academy of sciences.

44. http://www.leopoldina.org/en/policy-advice/science-for-politics-and-society/.

45. http://www.leopoldina.org/en/international-issues/international-academy-associations/.

46. http://www.leopoldina.org/en/international-issues/international-academy-associations/ easac/.

47. http://royalsociety.org/policy/.

48. http://royalsociety.org/uploadedFiles/Royal_Society_Content/policy/Science-Policy-Cen tre-Prospectus.pdf.

49. http://royalsociety.org/uploadedFiles/Royal_Society_Content/policy/Science-Policy-Cen tre-Prospectus.pdf.

50. http://www.academie-sciences.fr/en/mission.htm.

51. Un an avec l'Academie des sciences 2010-2011, p. 37.

52. Floc'h (2009) and Un an avec l'Academie des sciences 2010-2011, p. 22.

53. Un an avec l'Academie des sciences 2010-2011, pp. 25-6.

54. Calculations based on the information on http://erc.europa.eu/about-erc/organisation. 


\section{Prepublication version of chapter published in Linda Wedlin and Maria Nedeva (eds), Towards European Science: Dynamics and Change in Science Policy and Organization, 2015,

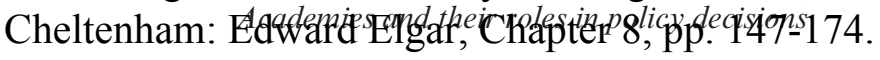 \\ REFERENCES}

Adam. D. (2002), 'Suspicions intensify over elusive European Academy of Sciences', Nature, 419, (31 October 2002), 865.

Ahrne, Göran and Nils Brunsson (2008), Meta-organizations, Cheltenham, UK and Northampton, MA, USA: Edward Elgar.

All-European-Academy Meeting (1993), The Role of Academies as Learned Societies in the New Europe, 17-18 March 1992: the All-European-Academy Meeting in Stockholm at the Royal Swedish Academy of Sciences: Summaries and Statements, Stockholm: Kungl. Vetenskapsakademien.

Alter, P. (1980), 'The Royal Society and the International Association of Academies 1897-1919', Notes and Records of the Royal Society, 34 (2), 241-64.

Bryson, Bill and Turney, Jon (eds) (2010), Seeing Further. The Story of Science \& the Royal Society, London: Harper Press.

Burgen, Arnold (2009), 'Academia Europaea: Origin and Early Days', European Review, 17 (3-4), 469-75.

Campbell, W. W. (1920), 'Report of the meetings of the International Research Council and the Affiliated Unions Held at Brussels, July 18-28, 1919', Proceedings of the National Academy of Sciences of the United States of America, 6 (6), 340-8.

Clery, D. (2011), 'ESF moves towards rebirth, but change worries some', Science, 331 (7 January), 16.

De Geer, Hans (1978), Rationaliseringsrörelsen i Sverige: effektivitetsidéer och socialt ansvar under mellankrigstiden (The rationalization movement in Sweden: Efficiency programs and social responsibility in the interwar years), Stockholm: SNS (diss.).

Drenth, Pieter J. D. (2006), Walks in the Garden of Science: Selected Papers and Lectures, Amsterdam: ALLEA.

Engelbrecht, Jüri and Nicholas Mann (2011), The Sum of the Parts: ALLEA and Academies, Amsterdam: ALLEA.

Engwall, Lars (2005), 'Hur har vi det med beredskapen idag? Utbildning och forskning som modern försvarspolitik' (What's the Preparedness today? Higher Education and Research as Modern Defence Policy), in Anders Björnsson, Martin Kylhammar and Åsa Linderborg (eds), Ord i rättan tid (Words at the Right Time), Stockholm: Atlantis, 281-300.

Engwall, Lars (2008), 'Minerva and the Media. Universities Protecting and Promoting Themselves', in Carmelo Mazza, Paolo Quattrone and Angelo Riccaboni (eds), European Universities in Transition: Issues, Models, and Cases, Cheltenham, UK and Northampton, MA, USA: Edward Elgar, 31-48.

Engwall, Lars (2012), 'From Collegium Curiosorum to Royal Society', in Lars Engwall (ed.), Scholars in Action: Past-Present-Future, Acta Universitatis Upsaliensis. Nova Acta Regiæ Societatis Scientiarum Upsaliensis, Ser. V, Uppsala: Uppsala University, 17-27.

Engwall, L. (2014a), 'The Recruitment of University Leaders: Politics, Communities and Markets in Interaction', Scandinavian Journal of Management, 30 (3), $332-43$.

Engwall, Lars (2014b), 'Corporate Governance and Communication', in Josef Pallas, Lars Strannegård and Stefan Jonsson (eds), Organizations and the Media, London: Routledge, 220-33. 
Prepublication version of chapter published in Linda Wedlin and Maria Nedeva (eds), Towards European Science: Dynamics and Change in Science Policy and Organization, 2015, diheltenham: Edward Elgar,,

ESF (2009), 'Strengthening the Role of Academies in ESF. An ESF-ALLEA High Level Workshop on ESF and the Academies, Brussels, 7 March 2008', Strasbourg: ESF.

European Review (2011), 'Focus: Academia Europaea: Founders and Founding Visions', European Review, 19 (2), 153-253.

Floc'h, Benoit (2009), 'Science+politique=intérêt général', Le Monde, 28 October, 3.

Frängsmyr, Tore (1989), 'Gubben som gräver - Vetenskapsakademien 250 år' (The Digging Man - the Royal Swedish Academy of Sciences 250 Years), in Tore Frängsmyr, Gubben som gräver: Människor och miljöer $i$ vetenskapens värld (The Digging Man: Persons and Settings in the World of Science), Stockholm: Författarförlaget Fischer \& Rye.

Grau, Conrad (1988), Berühmte Wissenschaftsakademien: von ihrem Entstehen und ihrem weltweitem Erfolg, Leipzig: Edition Leipzig.

Grunberg-Manago, Marianne (1979), 'The Role of the French Academy of Sciences', in: Proukakis, Charalambos and Katsaros, Nikos (eds), 1997, The New Role of the Academies of Sciences in the Balkan Countries, Dordrecht: Kluwer Academic Publishers, pp. 7-13.

Hahn, Roger (1971), The Anatomy of a Scientific Institution. The Paris Academy of Sciences, 1666-1803, Berkeley, Los Angeles, London: University of California Press.

Hildebrand, Bengt (1939), Kungl. Svenska Vetenskapsakademien: förhistoria, grundläggning och första organisation (The Royal Swedish Academy of Sciences: Prehistory, Foundation and the Early Organization), Stockholm: Kungl. Vetenskapsakademien.

ICSU (2011), ICSU Strategic Plan II, 2012-2017, Paris: International Council for Science.

Lane, Julia, Fealing, Kaye, Marburger, III, John, and Shipp, Stephanie (eds) (2011), The Science of Science Policy: A Handbook, Palo Alto, CA: Stanford University Press.

Jacob, François (2003), 'Recherche: jusqu'où ira le déclin?', Le Monde, April 8, 2003, p. 1.

Leopoldina (2010), A Tour of the German National Academy of Sciences Leopoldina, Halle: Leopoldina Nationale Akademie der Wissenschaften.

McClellan, James E. III (1985), Science Reorganized: Scientific Societies in the Eighteenth Century, New York: Columbia University Press.

Mittelstrass, J. (2010), 'The culture of science: on reason in scientific institutions', Nova Acta Leopoldina, NF, 113 (385), 65-77.

Porter, Michael E. (1990), The Competitive Advantage of Nations, New York: Free Press.

Science, 17 June 1904, 19 (494), 930-1.

Proukakis, Charalambos and Katsaros, Nikos (eds), (1997), The New Role of the Academies of Sciences in the Balkan Countries, Dordrecht: Kluwer Academic Publishers.

Quéré, Y. (2010), 'Academies must engage with society', Nature, 465 (24 June), 1009.

Un an avec l'Academie des sciences 2010-2011, Paris: Institut de France (Available at http://www.academie-sciences.fr/RA_sources/index-35.html).

Websites accessed in March 2013 and revisited in February 2014:

http://erc.europa.eu/about-erc/organisation. 


\section{Prepublication version of chapter published in Linda Wedlin and Maria Nedeva (eds), Towards European Science: Dynamics and Change in Science Policy and Organization, 2015,

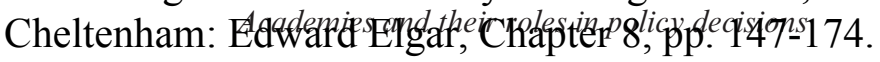

http://mta.hu. http://pau.krakow.pl. http://royalsociety.org/about-us. http://royalsociety.org/policy/. http://royalsociety.org/uploadedFiles/Royal_Society_Content/about-us/governance/ Statutes.pdf.

http://royalsociety.org/uploadedFiles/Royal_Society_Content/about-us/fellowship/ 130810_ElectionProcess.pdf.

http://royalsociety.org/uploadedFiles/Royal_Society_Content/policy/Science-Policy-

Centre-Prospectus.pdf.

http://rsc-src.ca.

http://www.aasa-net.org.

http://www.abc.org.br.

http://www.acad-ciencias.pt.

http://www.academieroyale.be.

http://www.academie-sciences.fr/en/mission.htm.

http://www.accademiadellacrusca.it.

http://www.accefyn.org.co/sp/history.htm.

http://www.ae-info.org/.

http://www.ae-info.org/ae/Acad_Main/About_us/Mission_Statement.

http://www.allea.org.

http://www.allea.org/Pages/ALL/4/982.bGFuZz1FTkc.html.

http://www.amphilsoc.org/.

http://www.anc-argentina.org.ar.

http://www.bbaw.de.

http://www.caets.org.

http://www.cas.cz/o_avcr/historie/.

http://www.dknvs.no.

http://www.easac.eu.

http://www.easac.eu/about-easac/easac-statutes.html.

http://www.easac.eu/home.html.

http://www.eurasc.org/aboutus/statutes.asp.

http://www.feam.eu.com.

http://www.fysiografen.se.

http://www.hazu.hr.

http://www.iamp-online.org.

http://www.icsu.org.

http://www.icsu.org/about-icsu/about-us.

http://www.ifs.se.

http://www.institut-de-france.fr/fr/une-institution/son-histoire.

http://www.interacademies.net.

http://www.interacademies.net/About/18456.aspx.

http://www.interacademies.net/Academies/11798/11025/IAS.aspx.

http://www.interacademycouncil.net.

http://www.interacademycouncil.net/23450/24788/24801.aspx.

http://www.iva.se.

http://www.kgaa.nu.

http://www.khmw.nl.

http://www.khvsu.se.

http://www.kkrva.se. 
Prepublication version of chapter published in Linda Wedlin and Maria Nedeva (eds), Towards European Science: Dynamics and Change in Science Policy and Organization, 2015,

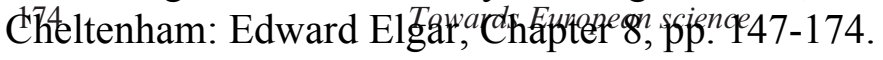

http://www.koms.se.

http://www.konstakademien.se.

http://www.ksla.se.

http://www.kungligasamfundet.se.

http://www.kva.se.

http://www.kvsu.se.

http://www.kvvs.se.

http://www.leopoldina.org/en/about-us/presidium-boards/statutes/.

http://www.leopoldina.org/en/international-issues/

international-academy-associations/easac/.

http://www.leopoldina.org/en/international-issues/ international-academy-associations/.

http://www.leopoldina.org/en/policy-advice/science-for-politics-and-society/. http://www.lincei.it/modules.php? name $=$ Content $\&$ pa $=$ showpage $\&$ pid $=21$.

http://www.lu.se/lucat/group/017080600.

http://www.musakad.se.

http://www.nasaconline.org.

http://www.ngzh.ch/.

http://www.rae.es.

http://www.ria.ie.

http://www.royalacademy.dk.

http://www.royalsoced.org.uk.

http://www.royalsociety.org.nz/organisation

http://www.royalsocietysa.org.za.

http://www.sanu.ac.rs.

http://www.skytteanskasamfundet.se.

http://www.svenskaakademien.se.

http://www.uai-iua.org.

http://www.vetenskapssocietetenuppsala.se.

http://www.vitterhetsakad.se.

http://yacadeuro.org/about-yae.htm. 